\title{
KOMPOSISI ASAM LEMAK, KOLESTEROL, DAN DESKRIPSI JARINGAN FILLET IKAN KAKAP MERAH SEGAR DAN GORENG
}

\section{Fatty Acid and Cholesterol Composition, and Tissues Description of Fresh and Fried Red Snapper Fillet}

\author{
Agoes Mardiono Jacoeb ${ }^{\star}$ Pipih Suptijah, Widyana Ayu Kristantina \\ Departemen Teknologi Hasil Perairan, Fakultas Perikanan dan Ilmu Kelautan, \\ Institut Pertanian Bogor, kampus IPB Darmaga, Jalan Agatis, Bogor, Jawa Barat 16680 \\ Telepon (0251) 8622909 -8622907, Faks. (0251) 8622907 \\ *Korespondensi: agoes59@yahoo.co.id; widyakristantina@gmail.com \\ Diterima 05 Januari 2015/Disetujui 20 April 2015
}

\begin{abstract}
Abstrak
Ikan kakap merah (Lutjanus argentimaculatus) merupakan ikan yang banyak dikonsumsi oleh masyarakat. Penelitian ini bertujuan untuk menentukan komposisi asam lemak, kolesterol, dan deskripsi jaringan fillet ikan kakap merah segar dan goreng. Komposisi asam lemak diuji dengan metode Gas Chromatografi (GC) dan kolesterol dengan metode Bohac. Ikan kakap merah segar memiliki kadar air 79,31\%, abu 1,92\%, protein 16,30\%, lemak 0,05\%, dan karbohidrat 0,23\%. Proses penggorengan mengakibatkan kadar air berubah menjadi $62,49 \%$, abu $1,98 \%$, protein $28,40 \%$, lemak 2,17\% dan, karbohidrat 5,62\%. Asam lemak jenuh yang dominan pada ikan kakap merah yaitu miristat (C14:0), palmitat (C18:0) dan stearat (C18:0). Asam lemak tak jenuh tunggal yang dominan yaitu palmitoleat (C16:1) dan oleat (C18:1). Asam lemak tak jenuh majemuk yang dominan yaitu linoleat (C18:2), linolenat (C18:3), arakidonat (C20:4), EPA (C20:5) dan DHA (C22:6). Kandungan kolesterol fillet kakap merah mengalami perubahan dari 20 $\mathrm{mg} / 100 \mathrm{~g}$ menjadi $60 \mathrm{mg} / 100 \mathrm{~g}$ sesudah proses penggorengan. Jaringan daging ikan kakap merah sebelum penggorengan tampak tidak kompak karena sudah mengalami proses penurunan mutu sedangkan daging ikan kakap merah setelah proses penggorengan tampak lebih kompak.
\end{abstract}

Kata kunci: Asam lemak, ikan kakap merah, jaringan daging, kolesterol, proksimat

Red Snapper is a widely consumed fish. The aim of this research was to determine the fatty acid and the cholesterol composition and to observe the tissues description of fresh and fried red snapper fillet. The fatty acid composition was tested using Gas Chromatography (GC) and the cholesterol with Bohac test. Fresh red snapper had moisture and protein content about $79.31 \%$ and $16.30 \%$, respectively. Meanwhile fried red snapper contained mosture and protein about $1.98 \%$ and $28.40 \%$, respectively. The highest compound of saturated fatty acid on red snapper were myristic acid; while of monounsaturated fatty acid were palmitoleat acid (C16:1). Of the polyunsaturated fatty acids, linoleic acid (C18:2) was found dominantly. Frying increased the cholesterol content from $20 \mathrm{mg} / 100 \mathrm{~g}$ to $60 \mathrm{mg} / 100 \mathrm{~g}$ of tissue. Tissue structure of fresh red snapper was found in not compact form because of low quality meat, however more compact structure was found on fried flesh of red snapper.

Keywords: Cholesterol, fatty acids, meat tissue, proximate, red snapper (L. argentimaculatus)

\section{PENDAHULUAN}

Sumberdaya perikanan Indonesia memiliki potensi yang sangat baik untuk berkontribusi di dalam pemenuhan gizi masyarakat Indonesia, baik perikanan tangkap maupun perikanan budidaya, salah satunya adalah ikan kakap merah. Ikan kakap merah merupakan salah satu jenis ikan demersal yang banyak terdapat di perairan laut Indonesia. Ikan ini banyak dikonsumsi oleh masyarakat dan memiliki nilai ekonomis tinggi. Produksi ikan kakap merah di Indonesia tahun 2007 sebesar 
116.994 ton dengan rata-rata kenaikan sebesar 4,83\% tiap tahunnya untuk komoditas ekspor (Statistik Kelautan dan Perikanan 2008). Teknik pengolahan yang biasanya dilakukan pada ikan kakap merah oleh masyarakat Indonesia adalah penggorengan.

Alireza et al. 2010 menyatakan bahwa menggoreng merupakan salah satu proses memasak bahan pangan secara cepat dan praktis menggunakan media minyak atau lemak panas. Metode ini banyak digunakan oleh masyarakat karena makanan yang digoreng memiliki sifat sensorik yang unik dan menarik, namun penggunaan minyak yang berulang akan berdampak pada nilai gizi. Bahan pangan yang diolah dengan panas biasanya akan mengalami kerusakan kandungan gizi, terutama lemak, protein, mineral, dan vitamin. Gizi yang terdapat dalam bahan pangan peka terhadap $\mathrm{pH}$ larutan, oksigen, cahaya, dan panas atau kombinasinya (Ketaren 2005). Proses pengolahan dapat mempengaruhi komposisi gizi, sehingga perlu dilakukan penelitian untuk menentukan kandungan asam lemak, kolesterol, dan deskripsi jaringan fillet ikan kakap merah segar dan goreng. Penelitian ini bertujuan untuk menentukan komposisi asam lemak, kolesterol, dan deskripsi jaringan fillet ikan kakap merah segar dan goreng.

\section{BAHAN DAN METODE}

\section{Bahan dan Alat}

Bahan yang digunakan adalah ikan kakap merah dan minyak goreng komersial, akuades, $\mathrm{HCl} 0,1 \mathrm{~N}$ (Merck), $\mathrm{NaOH} 40 \%$, katalis selenium, $\mathrm{H}_{2} \mathrm{SO}_{4}$ (Merck KGA), $\mathrm{H}_{3} \mathrm{BO}_{3} 2 \%$ (Mereck), kertas bromcresol green 0,1\% (Merck), dan methyl red 0,1\% (Merck), $\mathrm{NaOH} 0,5 \mathrm{~N}$ dalam metanol, $\mathrm{BF}_{3}$, $\mathrm{NaCl}$ jenuh, n-heksana, dan $\mathrm{Na}_{2} \mathrm{SO}_{4}$ anhidrat, petroleum benzen, alkohol, $\mathrm{FeCl}_{3} \cdot 6 \mathrm{H}_{2} \mathrm{O}$, dan $\mathrm{H}_{2} \mathrm{SO}_{4}$ pekat.

Alat-alat yang digunakan adalah oven, desikator, tanur, homogenizer, evaporator, erlenmeyer (ekstraksi asam lemak), dan botol vial (metilasi), serta perangkat kromatografi gas Shimadzu GC 2010, spektrofotometer, dan mikroskop cahaya Olympus CX41.

\section{Metode Penelitian}

Penelitian ini dimulai dengan pengambilan sampel dari pasar tradisional di Gunung Batu, Bogor, Jawa Barat, Indonesia. Ikan kakap merah (L. argentimaculatus) dianalisis morfometriknya, meliputi bobot total, panjang total, panjang baku, lebar, dan tinggi badan. Daging, jeroan, tulang, dan sisik dipisahkan dan dihitung rendemennya. Sampel disimpan pada suhu chilling.

Penggorengan dilakukan dengan memasukkan sampel dalam panci penggorengan yang berisi $3 \mathrm{~L}$ minyak dan dipanaskan dengan suhu $130^{\circ} \mathrm{C}$ selama 5 menit, kemudian didinginkan selama 5 menit pada suhu ruang. Sebelum dan sesudah proses penggorengan dilakukan penimbangan untuk mengetahui penyusutan bobot daging ikan kakap merah.

Sampel yang diperoleh dilakukan penghitungan rendemen, analisis proksimat, analisis asam lemak, analisis asam lemak bebas, analisis kandungan kolesterol, dan pengamatan deskripsi jaringan. Perhitungan rendemen dilakukan berdasarkan bobot contoh dan bobot total sampel. Analisis proksimat merupakan analisis yang dilakukan untuk mengetahui komposisi kimia suatu bahan yang meliputi, analisis kadar air, lemak, protein, abu, dan karbohidrat by difference (BSN 1992). Analisis asam lemak dilakukan dengan metode kromatografi gas (AOAC 2005 butir 996.06). Analisis asam lemak bebas dengan metode titrasi (BSN 1994). Analisis kolesterol dilakukan dengan metode Bohac et al. (1988). Pengamatan preparat jaringan dilakukan dengan metode parafin (Angka et al. 1984).

\section{HASIL DAN PEMBAHASAN \\ Karakteristik Bahan Baku}

Sampel ikan kakap merah yang digunakan memiliki ciri bentuk tubuh pipih, posisi mulut terminal, sirip ekor tegak, jumlah sirip lengkap, yaitu dorsal, pektoral, ventral, anal, caudal. Nilai rata-rata panjang total ikan kakap merah adalah $(38,67 \pm 1,67) \mathrm{cm}$, panjang baku rata-rata $(23,33 \pm 2,88) \mathrm{cm}$, tinggi ratarata $(10,50 \pm 1,38) \mathrm{cm}$, lebar rata-rata adalah 
$(4,83 \pm 0,41) \mathrm{cm}$ dan bobot total rata-rata adalah $(900,83 \pm 82,71)$ g. Metusalach (2007) menyatakan bahwa morfometrik suatu biota dipengaruhi oleh faktor eksternal dan internal. Faktor eksternal adalah habitat, musim, suhu perairan, jenis makanan yang tersedia, dan faktor lingkungan lainnya sedangkan faktor internal adalah umur, ukuran, jenis kelamin, kebiasaan makan, dan faktor biologis lainnya.

\section{Rendemen Ikan Kakap Merah}

Rendemen adalah persentase bagian bahan baku yang dapat dimanfaatkan. Bagian tubuh ikan kakap merah yang dapat dimanfaatkan adalah daging, tulang, jeroan, dan sisik. Presentase bagian tubuh ikan kakap merah adalah daging 39\%, tulang $45 \%$, jeroan $12 \%$, dan sisik $4 \%$. Bagian tubuh yang dapat dimanfaatkan dari ikan kakap tidak hanya daging. Penelitian Sartika (2009) menunjukkan tulang dan kulit ikan kakap merah dapat diolah menjadi gelatin. Ali et al. (2011) menyatakan sisik ikan kakap merah dapat diekstrak menjadi kolagen.

Perlakuan penggorengan menyebabkan terjadinya penyusutan atau kehilangan berat (lost) 24\% dari bobot daging. Proses penggorengan menyebabkan terjadinya pengurangan kadar air pada daging kakap merah. Keluarnya air dari jaringan daging akan menyebabkan komponen zat gizi lain juga berkurang yaitu protein, lemak, vitamin dan mineral sehingga nilai rendemen daging juga akan susut.

\section{Komposisi Kimia Ikan Kakap Merah}

Kadar air daging ikan kakap merah segar adalah $79,31 \%$ dan setelah penggorengan berubah menjadi $62,49 \%$. Penurunan kadar air disebabkan adanya perlakuan penggorengan sehingga molekul air dalam bahan akan terlepas (Winarno 2008).

Kadar abu ikan kakap merah segar hasil analisis adalah 8,78\% (bk) dan mengalami penurunan pada fillet goreng menjadi 5,19\% (bk). Abu merupakan residu anorganik dari proses pembakaran atau oksidasi komponen organik bahan pangan. Kadar abu bahan pangan menunjukkan total mineral yang terkandung dalam bahan pangan tersebut (Winarno 2008). Choe dan Min (2007) menyatakan bahwa kndungan mineral dalam suatu bahan dapat berubah ketika proses penggorengan karena minyak mengandung natrium atau kalium $<1 \mathrm{ppm}$.

Kadar protein fillet kakap merah segar adalah $74,53 \%$ (bk) dan mengalami penurunan menjadi $74,40 \%$ (bk) setelah penggorengan. Puwastien et al. (1999) dalam penelitiannya terhadap ikan kakap merah (L. malabaricus) yang menunjukkan kadar protein ikan kakap merah berubah dari $18,1 \%$ menjadi 29,8\% setelah penggorengan. Perubahan kadar protein pada ikan berkaitan dengan penyusutan kadar air pada ikan selama proses penggorengan. Semakin besar penyusutan kadar air pada ikan setelah pemasakan, semakin besar pula perubahan kadar protein pada ikan (Devi dan Sarojnalini 2012).

Kadar lemak fillet kakap merah segar sebesar $0,23 \%$ (bk) dan mengalami peningkatan menjadi 5,69\% (bk) setelah penggorengan. Puwastien et al. (1999) terhadap ikan kakap merah (L. malabaricus) menunjukkan kadar lemak berubah dari 0,5\% menjadi $10,9 \%$ setelah proses penggorengan. Kandungan lemak fillet kakap merah segar dan goreng berbeda karena pada proses penggorengan ada pengaruh suhu dengan memakai minyak. Lemak merupakan senyawa organik yang terdapat di alam yang tidak larut dalam air tetapi dapat larut dalam pelarut organik non polar dan merupakan komponen utama dalam jaringan adiposa (Arvanitoyannis et al. 2010).

Kandungan karbohidrat fillet kakap merah segar adalah $16,46 \%$ (bk) dan fillet goreng adalah $14,72 \%$ (bk). Kandungan karbohidrat pada ikan biasanya sangat sedikit yaitu berkisar antara 0,1-1\% (Nurjanah dan Abdullah 2010).

\section{Asam Lemak Fillet Ikan Kakap Merah}

Kandungan asam lemak jenuh pada 
fillet kakap merah segar adalah $17,43 \%$ dan fillet kakap merah goreng adalah 35,90\%. Kandungan asam lemak tak jenuh tunggal pada fillet kakap merah segar adalah $7,31 \%$ dan fillet kakap merah goreng adalah 34,48\%. Kandungan asam lemak tak jenuh ganda pada fillet kakap merah segar adalah 10,8\% dan fillet kakap merah goreng adalah $11,66 \%$ (Tabel 1). Variasi asam lemak pada organisme perairan dapat dipengaruhi oleh pergantian musim, letak geografis, salinitas lingkungan (Ozyurt et al. 2006), dan perlakuan yaitu hidup bebas di alam atau dibudidayakan (Kandemir dan Polat 2007).

Asam lemak jenuh (SFA) merupakan asam lemak yang mengandung ikatan tunggal pada rantai hidrokarbonnya. Kandungan asam lemak jenuh yang paling banyak ditemukan pada daging ikan kakap merah adalah asam palmitat (C16:0), stearat (C18:0) dan miristat (C14:0) (Gambar 1). Kandungan asam lemak palmitat meningkat 3 kali lipat setelah penggorengan disebabkan tercampurnya asam palmitat yang berasal dari minyak goreng. Kandungan asam palmitat minyak kelapa sawit sekitar 42,6\% (Abiona et al. 2011). Asam palmitat merupakan komponen utama dalam asam lemak jenuh yaitu $53-65 \%$ dari total asam lemak jenuh (Ozugul dan Ozugul 2007). Kandungan asam palmitat yang meningkat sesuai dengan penelitian Alireza et al. (2010) yaitu asam palmitat pada minyak dapat meningkat setelah proses deep frying.

Asam lemak tak jenuh tunggal (MUFA) merupakan asam lemak yang mengandung ikatan rangkap sebanyak satu pada rantai hidrokarbonnya. Asam lemak tak jenuh tunggal yang dominan adalah asam oleat (C18:1), palmitoleat (C16:1) (Gambar 2). Kandungan asam oleat pada fillet kakap merah mengalami kenaikan 8 kali lipat setelah penggorengan. Perubahan ini disebabkan adanya percampuran asam oleat yang berasal dari minyak goreng. Kandungan asam oleat minyak kelapa sawit $\pm 30,91 \%$ (Chedoloh et al. 2011).

Asam lemak tak jenuh majemuk (PUFA) merupakan asam lemak yang mengandung ikatan rangkap lebih dari satu pada rantai hidrokarbonnya. Asam lemak tak jenuh majemuk yang dominan pada fillet kakap merah (L. argentimaculatus) adalah asam linoleat (C18:2), linolenat (C18:3), arakidonat (C20:4), EPA (C20:5) dan DHA (C22:6) (Gambar 3). Kandungan asam linoleat meningkat 26 kali setelah proses penggorengan disebabkan oleh tercampurnya asam linoleat yang berasal dari minyak goreng dan penurunan kadar air. Kandungan asam linoleat pada minyak kelapa sawit sebesar 9,23\%. Hasil penelitian Chedoloh et al. (2011) terhadap ikan kakap (L. johnii) menunjukkan pola yang sama, yaitu PUFA yang dominan dalam ikan kakap (L. johnii) adalah asam arakidonat (C20:4), asam linoleat (C18:2) dan asam linolenat (C18:3), EPA, dan DHA.

Kandungan asam arakidonat mengalami penurunan 5 kali setelah proses penggorengan.

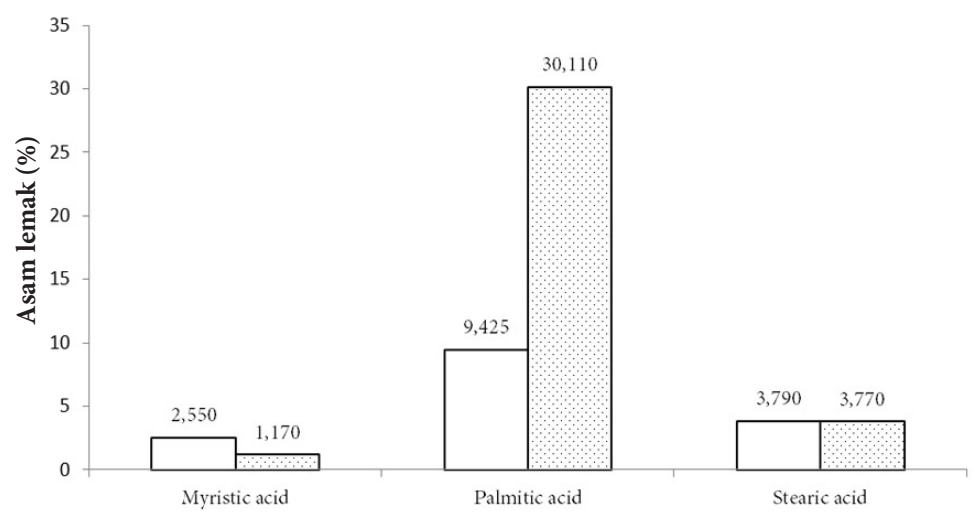

Gambar 1 Kandungan Asam lemak jenuh fillet kakap merah, segar $(\square)$; goreng $(\square)$ 
Tabel 1 Kandungan asam lemak fillet kakap merah segar dan goreng

\begin{tabular}{|c|c|c|c|c|c|}
\hline \multirow[b]{2}{*}{ Komponen } & \multicolumn{3}{|c|}{ Kakap merah } & \multicolumn{2}{|c|}{ Sea bass ${ }^{* *}$} \\
\hline & $\begin{array}{l}\text { Segar } \\
(\%)\end{array}$ & $\begin{array}{l}\text { Goreng } \\
(\%)\end{array}$ & $\begin{array}{c}\text { Minyak } \\
\text { goreng } \\
(\%)^{*}\end{array}$ & $\begin{array}{l}\text { Segar } \\
(\%)\end{array}$ & $\begin{array}{l}\text { Goreng } \\
(\%)\end{array}$ \\
\hline Capric acid (C10:0) & - & - & 0,02 & - & - \\
\hline Lauric acid (C12:0) & 0,075 & 0,11 & 0,15 & 0,05 & 0,03 \\
\hline Myristic acid (C14:0) & 2,55 & 1,165 & 0,75 & 4,11 & 2,71 \\
\hline Pentadecanoic acid (C15:0) & 0,29 & 0,105 & 0,03 & 0,60 & 0,40 \\
\hline Palmitic acid (C16:0) & 9,425 & 30,11 & 33,09 & 19,46 & 15,47 \\
\hline Heptadecanoic acid (C17:0) & 0,435 & 0,16 & 0,07 & 0,98 & 0,68 \\
\hline Stearic acid (C18:0) & 3,79 & 3,77 & 3,72 & 3,90 & 4,47 \\
\hline Arachidic acid (C20:0) & 0,21 & 0,305 & 0,33 & 1,45 & 0,93 \\
\hline Heneicosanoic acid (C21:0) & 0,05 & - & - & 0,34 & 0,06 \\
\hline Behenic acid (C22:0) & 0,32 & 0,085 & 0,06 & 0,81 & 0,65 \\
\hline Tricosanoic acid (C23:0) & 0,07 & - & - & 0,30 & 0,41 \\
\hline Lignoceric acid (C24:0) & 0,215 & 0,085 & 0,06 & 0,88 & 0,66 \\
\hline Jumlah & 17,43 & 35,895 & 38,26 & 32,88 & 26,47 \\
\hline Myristoleic acid (C14:1) & 0,22 & 0,03 & - & 0,12 & 0,07 \\
\hline Palmitoleic acid (C16:1) & 2,41 & 0,615 & 0,15 & 6,09 & 3,84 \\
\hline Elaidic acid (C18:1n9t) & 0,105 & 0,085 & - & - & - \\
\hline Oleic acid $(\mathrm{C} 18: \ln 9 \mathrm{c})$ & 4,12 & 33,715 & 40,25 & 23,16 & 22,44 \\
\hline Cis-11-Eicosenoic acid (C20:1) & 0,13 & - & 0,15 & 2,39 & 1,63 \\
\hline Cis-11,14-Eicosedienoic acid (C20:2) & 0,09 & - & 0,05 & 0,59 & 0,44 \\
\hline Erucid acid (C22:1n9) & 0,055 & - & - & 0,65 & 0,27 \\
\hline Nervonic acid (C24:1) & 0,18 & 0,03 & - & 1,64 & 1,13 \\
\hline Jumlah & 7,31 & 34,475 & 40,6 & 34,64 & 29,82 \\
\hline Linoleic acid (C18:3n3) & 0,36 & 9,37 & 10,55 & 9,85 & 27,08 \\
\hline$\gamma$-Linolenic acid (C18:3n6) & 0,02 & - & - & 0,22 & 0,15 \\
\hline Linolenic acid (C18:3n3) & 0,09 & 0,17 & 0,17 & 0,39 & 0,33 \\
\hline $\begin{array}{l}\text { Cis-8,11,14-Eicosentrienoic acid } \\
\text { (C20:3n6) }\end{array}$ & 0,065 & - & - & - & - \\
\hline $\begin{array}{l}\text { Cis-11,14,17-Eicosentrienoic acid } \\
\text { (C20:3n3) }\end{array}$ & 0,03 & - & - & 0,14 & 0,08 \\
\hline Arachidonic acid (C20:4n6) & 2,15 & 0,4 & - & - & - \\
\hline $\begin{array}{l}\text { Cis-5,8,11,14,17-Eicosapentaenoic acid } \\
\text { (C20:5n3) }\end{array}$ & 1,55 & 0,36 & - & 5,58 & 3,93 \\
\hline $\begin{array}{l}\text { Cis-4,7,10,13,16,19-Decosahexaenoic } \\
\text { acid (C22:6n3) }\end{array}$ & 6,535 & 1,355 & - & 15,11 & 10,91 \\
\hline Jumlah & 10,8 & 11,655 & 10,72 & 31,29 & 42,48 \\
\hline
\end{tabular}

Keterangan : ${ }^{\star}$ minyak goreng komersial; ${ }^{\star \star}$ Turkkan et al. (2008) 


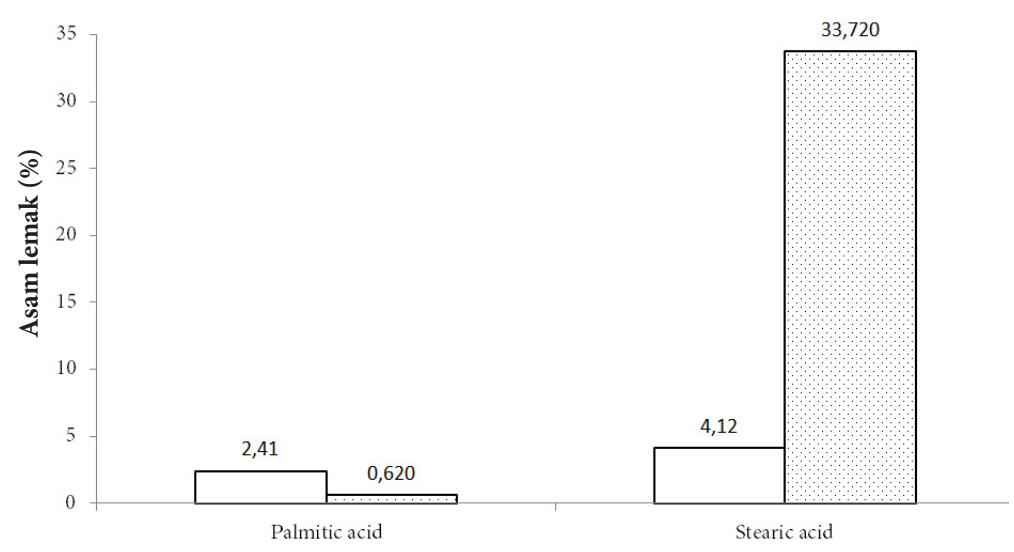

Gambar 2 Kandungan Asam lemak tak jenuh tunggal fillet kakap merah, segar $(\square)$; goreng $(\square)$

Dekomposisi oksidatif pada asam lemak tidak jenuh selama proses pemanasan lebih mudah terjadi karena ikatan rangkapnya lebih mudah diserang oleh oksigen (Winarno 2008). Kandungan EPA dan DHA pada fillet kakap merah mengalami penurunan 4 kali akibat penggorengan. Asam lemak esensial seperti DHA dan EPA sensitif terhadap sinar, suhu dan oksigen, hal inilah yang menyebabkan kandungan DHA dan EPA pada fillet kakap merah mengalami penurunan. Arias et al. (2003) menyatakan kandungan DHA pada Sardine pilchardus mengalami penurunan setelah dilakukan pengolahan dengan panas. Asam lemak linolenat merupakan prekursor asam lemak omega-3 yang dijumpai dalam tubuh manusia yaitu
EPA (eicosapentaenoic acid) dan DHA (docosahexaenoic acid). EPA dan DHA merupakan asam lemak tak jenuh yang berperan penting dalam kesehatan tubuh manusia serta merupakan komponen struktural terbesar dalam membran fosfolipid yang mengatur fluiditas membran dan transport ion (Chapkin et al. 2008)

\section{Kandungan Asam Lemak Bebas Fillet Ikan Kakap Merah (L. Argentimaculatus)}

Kandungan asam lemak bebas pada fillet segar berdasarkan hasil penelitian adalah $13,43 \%$ dan pada fillet goreng berubah menjadi 4,14\%. Nilai ini cukup tinggi dibandingkan dengan SNI 01-3741-1995 yang menetapkan batas maksimal kandungan asam

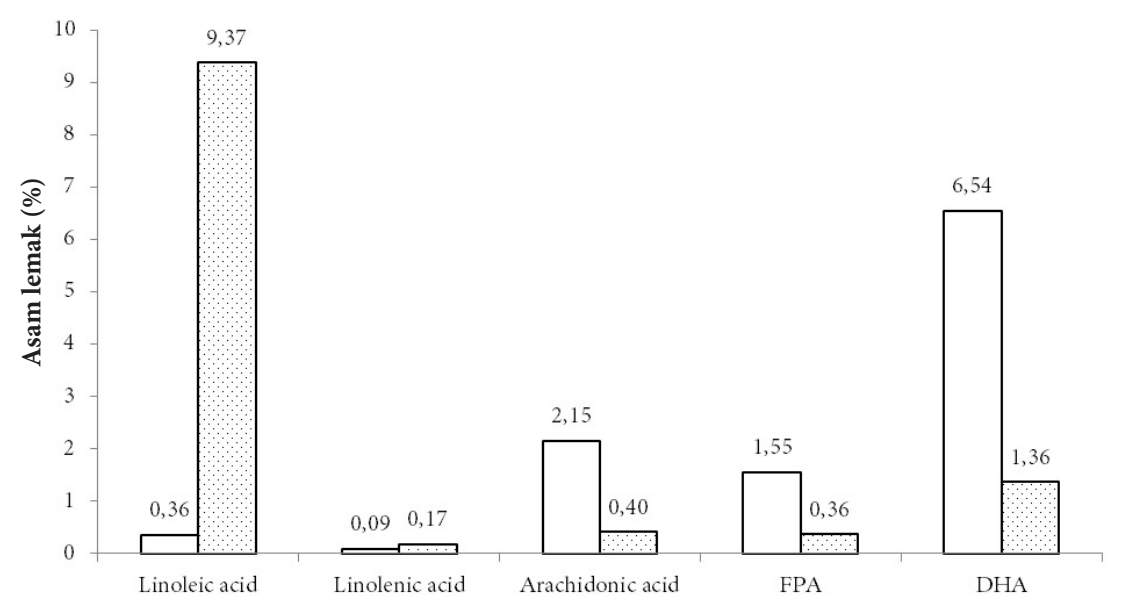

Gambar 3 Kandungan Asam lemak tak jenuh majemuk fillet ikan kakap merah, segar $(\square)$; goreng $(\square)$ 
lemak bebas minyak sebesar 0,3\% (BSN 1995). Aroet al. (2000) menyatakan terjadipenurunan asam lemak bebas pada ikan herring Baltic akibat penggorengan. Menurut Weber et al. (2008), perubahan ini disebabkan karena saat proses pemanasan terjadi penurunan aktivitas enzim lipase yang akan mencegah terlepasnya asam lemak bebas.

Asam lemak bebas adalah asam lemak yang berada sebagai asam bebas tidak terikat sebagai trigliserida. Pembentukan asam lemak bebas terjadi karena proses hidrolisis dan oksidasi minyak yang disebabkan oleh keberadaan radikal bebas serta penguraian ikatan rangkap selama pemanasan (Paul dan Mittal 1997). Minyak goreng merupakan medium penggoreng bahan makanan yang berfungsi sebagai penghantar panas. Minyak akan mengalami pemanasan yang menyebabkan perubahan fisika-kimia sehingga berpengaruh terhadap minyak tersebut dan bahan yang digoreng. Salah satu indikator kerusakan minyak adalah asam lemak bebas. Asam lemak bebas terbentuk karena proses oksidasi dan hidrolisis enzim selama pengolahan dan penyimpanan (Aminah dan Isworo 2010).

\section{Kandungan Kolesterol Fillet Ikan Kakap Merah (L. Argentimaculatus)}

Kandungan kolesterol fillet ikan kakap merah segar adalah $20 \mathrm{mg} / 100 \mathrm{~g}$. Hasil ini lebih rendah dibandingkan Mathew et al. (1999) yaitu sebesar 95,5 mg/ 100 g. Pada fillet ikan kakap merah goreng kandungan kolesterol mengalami perubahan menjadi $60 \mathrm{mg} / 100 \mathrm{~g}$. Zivkovic et al. (2002) menyatakan kandungan kolesterol pada ikan dipengaruhi oleh spesies, jenis kelamin, musim, nutrisi pakan dan kandungan asam lemak tak jenuh majemuk.

Kolesterol merupakan substrat yang tidak larut air untuk pembentukan beberapa zat esensial, yaitu sintesis asam empedu yang penting untuk penyerapan lemak serta hormon testosteron, estrogen, progesteron dan kortisol. Kolesterol diproduksi dalam tubuh terutama oleh hati, tetapi jika produksi kolesterol berlebihan dapat meningkatkan risiko penyumbatan pembuluh arteri (Colpo 2005). Abiona et al. (2011) menyatakan kandungan asam lemak jenuh pada minyak kelapa dapat meningkatkan kandungan kolesterol pada bahan yang digoreng.

\section{Deskripsi Jaringan Daging Ikan Kakap Merah (L. Argentimaculatus)}

Analisis jaringan daging ikan kakap merah dilakukan untuk melihat perbedaan struktur daging ikan kakap sebelum dan sesudah penggorengan. Struktur daging ikan kakap merah segar dapat dilihat pada Gambar 4a dan $4 \mathrm{~b}$, sedangkan struktur daging ikan kakap goreng dapat dilihat pada Gambar 5a dan 5b. Gambar 4a menunjukkan daging ikan kakap merah sebelum penggorengan telah terjadi proses penurunan kesegaran ikan (rigor mortis) yang disebabkan aktivitas bakteri dan enzim. Susunan jaringan daging ikan kakap merah terlihat tidak kompak dan terputus-putus. Gambar 4a dan 4b menunjukkan struktur daging ikan kakap merah lebih kompak dan rapat dibandingkan sebelum penggorengan. Pemasakan ikan dengan penggorengan mampu menghambat proses penurunan mutu ikan. Gambar 4b merupakan penampang jaringan pada kulit ikan kakap merah segar. Struktur kulit ikan tidak berbeda dengan kulit vertebrata lainnya, yaitu terdiri dari dua lapisan utama yakni epidermis luar dan dermis dalam.

Pemanasan menyebabkan protein bahan terdenaturasi sehingga kemampuan mengikat airnya menurun. Energi panas akan mengakibatkan terputusnya interaksi nonkovalen yang ada pada struktur alami protein tapi tidak memutuskan ikatan kovalennya yang berupa ikatan peptida. Proses ini biasanya berlangsung pada kisaran suhu yang sempit, hal ini dikarenakan suhu tinggi dapat meningkatkan energi kinetik dan menyebabkan molekul penyusun protein bergerak atau bergetar sangat cepat sehingga mengacaukan ikatan molekul tersebut (Pattipeilohy 2006). 

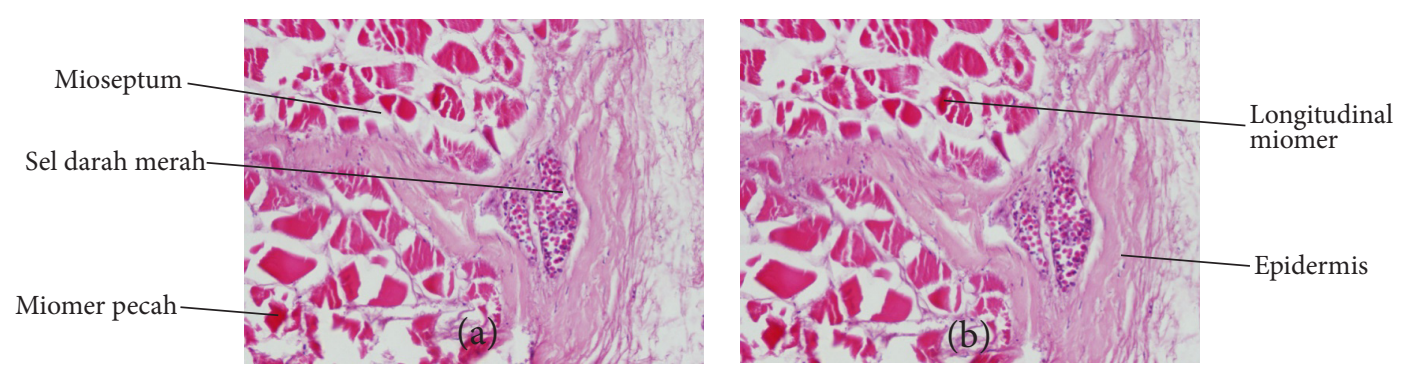

Gambar 4 Struktur jaringan daging (a) dan kulit (b) ikan kakap merah segar
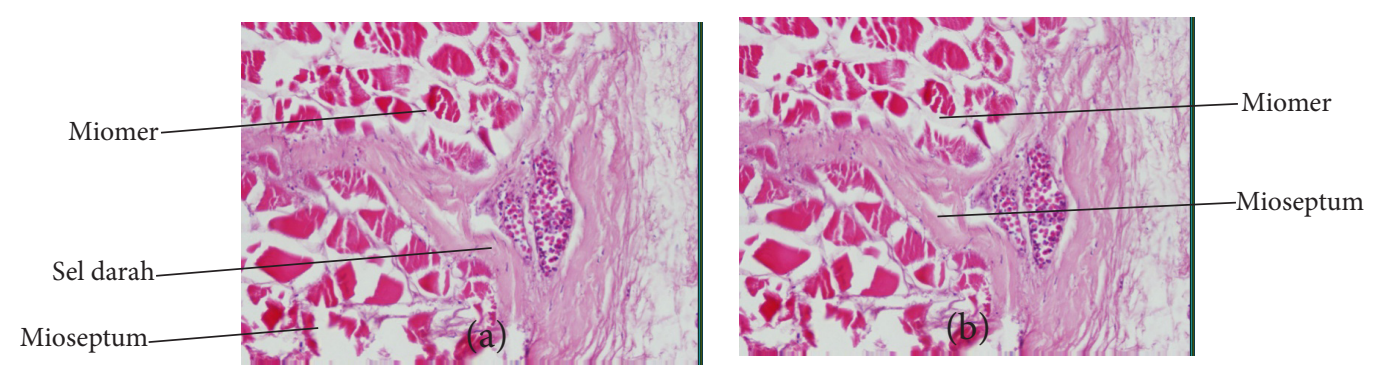

Gambar 5 Struktur jaringan daging (a) dan kulit (b) ikan kakap merah goreng

\section{KESIMPULAN}

Asam lemak jenuh yang dominan yaitu asam miristat (C14:0), asam palmitat (C18:0) dan asam stearat (C18:0). Asam lemak tak jenuh tunggal yang dominan yaitu asam palmitoleat (C16:1) dan asam oleat (C18:1). Kandungan asam oleat pada fillet kakap merah segar mengalami peningkatan 8 kali setelah penggorengan. Asam lemak tak jenuh majemuk yang dominan yaitu asam linoleat (C18:2), linolenat (C18:3), arakidonat (C20:4), EPA (C20:5) dan DHA (C22:6). Kandungan kolesterol pada fillet kakap merah mengalami peningkatan 3 kali setelah proses penggorengan. Struktur jaringan pada daging ikan kakap merah sebelum proses penggorengan tampak tidak kompak karena sudah mengalami proses penurunan mutu sedangkan daging ikan kakap merah setelah proses penggorengan tampak lebih kompak.

\section{DAFTAR PUSTAKA}

[AOAC] Association of Official Analytical Chemist. 2005. Official Method of Analysis of The Association of Official Analytical of Chemist. Arlington: The Association of Official Analytical Chemist, Inc.
Abiona OO, Awojide SH, Anifowoshe AJ, Babalola OB. 2011. Comparative study on effect of frying process on the fatty acid profile of vegetable oil and palm oil. E-International Scientific Research Journal 3(3):210-219.

Ali M, Noor NM, Leksono YS. 2011. Ekstraksi kolagen dari sisik ikan kakap merah (Lutjanus sp.). Prosiding Seminar Nasional Pengolahan Produk dan Bioteknologi Kelautan dan Perikanan II; 9 Agustus 2010.

Alireza S, Tan CP, Hamed M, Man CYB. 2010. Effect of frying process on fatty acid composition and iodine value of selected vegetable oils and their blends. International Food Researh Journal 17: 295-302.

Aminah S, Isworo J. 2010. Praktek Penggorengan Dan Mutu Minyak Goreng Sisa Pada Rumah Tangga di Rt V Rw III Kedungmundu Tembalang Semarang. Prosididng Seminar Nasional UNIMUS 2010.

Angka SL, Mokoginta I, Dana D. 1984. Pengendalian Penyakit Ikan, Histologi, dan Hematologi Ikanikan Air Tawar yang Dibudidayakan. 
Bogor: Departemen Pendidikan dan Kebudayaan. Direktorat Jenderal Pendidikan Tinggi. Institut Pertanian Bogor.

Arias MT, Pontes E, Linares G. 2003. Cooking-freezing-reheating (CFR) of sardine (Sardine pilchardus) fillets, effect of different cooking dan reheating procedures on the proximate dan fatty acid composition. Food Chemistry 83:349-356.

Aro T, Tahvonen R, Mattila T, Nurmi J, Sivonen T, Kallio H. 2000. Effects of season and processing on oil content and fatty acids of Baltic herring (Clupea harengus membras). Journal of Agricultural and Food Chemistry 48: 6085-6093.

Arvanitoyannis IS, Varzakas TH, Kiokias S, Labropoulos AE. 2010. Lipids, fats, dan oils. Di dalam:Yildiz F, editor. Advances in Food Biochemistry. London: CRC Press. Taylor \& Francis Group.

[BSN] Badan Standardisasi Nasional. 1992. SNI 01-2891-1992. Cara Uji Makanan dan Minuman. Jakarta: Dewan Standarisasi Nasional.

[BSN] Badan Standardisasi Nasional. 1994. SNI 01-3555-1994. Cara Uji Minyak dan Lemak. Jakarta: Dewan Standarisasi Nasional.

[BSN] Badan Standardisasi Nasional. 1995. SNI 01-3741-1995. Standar Mutu Minyak Goreng. Jakarta : Dewan Standarisasi Nasional.

Bohac CE, Rhee KS, Cross HR, Ono K. 1988. Assessment of methodologies for colorimetric cholesterol assay of meats. Journal of Food Science 53(6):16421644.

Chapkin R, McMurray D, Davidson L, Patil B, Lupton J. 2008. Bioactive dietary long-chain fatty acids: emerging mechanisms of action. British Journal of Nutrition 100:1152-1157.

Chedoloh R, Karrila TT, Pakdeechaunan
P. 2011. Fatty acid composition of important aquatic animals in Southern Thailand. International Food Research Journal 18:783-790.

Choe E, Min DB. 2007. Chemistry of deepfat frying oils. Journal of Food Science 72(5): 77-87.

Colpo A. 2005. LDL cholesterol: bad cholesterol or bad science. Journal of American Physicians dan Surgeons 10(3):83-89.

Devi WS, Sarojnalini C. 2012. Impact of different cooking methods on proximate and mineral composition of Amblypharyngodon mola of Manipur. International Journal of Advanced Biological Research 2(4):641-645.

Kandemir S, Polat N. 2007 Seasonal variation of total lipid and total fatty acid in muscle and liver of rainbow trout (Oncorhynchus mykiss W 1792) reared in derbent dam lake. Turkish Journal of Fisheries and Aquatic Science 7:27-31.

Ketaren S. 2005. Pengantar Teknologi Minyak dan Lemak Pangan. Jakarta: UI-Press.

Mathew S, Ammu K, Nair V, Devadasan K. 1999. Cholesterol content of Indian fish and shellfish. Food Chemistry 66:455-461.

Metusalach. 2007. Pengaruh fase bulan dan ukuran tubuh terhadap rendemen, kadar protein, air dan abu daging kepiting rajungan, Portunus spp. Jurnal Ilmu Kelautan dan Perikanan Universitas Hasanuddin 17(3):233-239.

Nurjanah, Abdullah A. 2010. Cerdas Memilih Ikan dan Mempersiapkan Olahannya. Bogor: IPB Press.

Ozugul Y, Ozugul F. 2007. Fatty acid profiles of commercially important fish species from the mediterranean, agean dan black seas. Food Chemistry 100(4): 1634-1638.

Ozyurt G, Duysak O, Akamca E, Tureli C. 2006. Seasonal changes of fatty acids of 
cuttlefish Sepia officinalis L. (mollusca: cephalopoda) in the north eastern mediterranean sea. Food Chemistry 95(3):382-385.

Pattipeilohy F. 2006. Pengolahan fish burger dengan memanfaatkan ikan rucah. Ichthyos 6(1): 27-34.

Paul S, Mittal GS. 1997. Regulating the use of degraded oil/fat/in deep-fat/oil food frying. Critical Rev in Food Science and Nutrient 37(7):635-662.

Puwastien P, Judprasong K, Kettwan E, Vasanachitt K, Nakngamanong Y, Bhattacharjee L. 1999. Proximate composition of raw and cooked Thai fresh water and marine fish. Journal of Food Composition and Analysis 12(3):9-16.

Sartika A. 2009. Pengaruh suhu dan lama proses menggoreng (deep frying) terhadap pembentukkan asam lemak trans. Makara Sains 13(1):23-28.
Statistik Kelautan dan Perikanan. 2008. Statistik perikanan tangkap Indonesia. Jakarta: Kementerian Kelautan dan Perikanan.

Turkkan AU, Cakli S, Kilinc B. 2008. Effects of cooking methods on the proximate composition and fatty acid composition of seabass (Dicentrarchus labrax, Linnaeus, 1758). Food and Bioproducts Processing 86:163-166.

Weber J, Vivian CB , Cristiane PR, Andre', Tatiana E. 2008. Effect of different cooking methods on the oxidation, proximate and fatty acid composition of silver catfish (Rhamdia quelen) fillets. Food Chemistry 106:140-146.

Winarno FG. 2008. Kimia Pangan dan Gizi. Bogor: Embrio Press.

Zivkovic D, Peric V, Barac M, Perunovic M. 2002. Cholesterol content in meat of some Cyprinidae. Journal of Agricultural Science 47(2):179-187. 